\title{
An empirical study on open position risk assessment using VAR and regression analysis: A case
} study of Iranian banking industry

\author{
Mohammad Khodaei Valahzaghard $^{\mathrm{a}^{*}}$, Mina Ghavidel ${ }^{\mathrm{b}}$, Mojtaba Heidar ${ }^{\mathrm{b}}$ and Elmira Mahmoudzadeh ${ }^{\mathrm{c}}$
}

\begin{abstract}
${ }^{a}$ Assist.Prof. \& Faculty Member, Department of Accounting, Tehran North Branch, Islamic Azad University (IAU), Tehran, Iran
${ }^{b}$ M.A. Student, Department of Accounting, Tehran North Branch, Islamic Azad University (IAU), Tehran, Iran

${ }^{c}$ M.A. Student, Department of Accounting, Islamshahr Branch, Islamic Azad University (IAU), Tehran, Iran

\begin{tabular}{|c|c|}
\hline ART I C LE I NFO & A B S T R A T \\
\hline $\begin{array}{l}\text { Article history: } \\
\text { Received March 21, } 2012 \\
\text { Received in Revised form } \\
\text { April, 25, } 2012 \\
\text { Accepted } 30 \text { May } 2012 \\
\text { Available online } \\
\text { June } 52012 \\
\text { Keywords: } \\
\text { Open Position } \\
\text { Net Foreign Currency Balance } \\
\text { Sheet Items (NFCBSI) } \\
\text { Foreign Currency Assets } \\
\text { Foreign Currency Liabilities }\end{array}$ & $\begin{array}{l}\text { During the past few years, there have been tremendous fluctuations on different currencies. For } \\
\text { instance, European common currency, Euro, has be fluctuated between } 0.60 \text { to } 0.9 \text { against US } \\
\text { dollar. Therefore, it is important to study the behavior of currency valuations using different } \\
\text { techniques. In this paper, we present an empirical study to measure the impact of different items } \\
\text { on risk of foreign currency using value at risk (VaR) and regression methods. The proposed } \\
\text { model of this paper investigates whether the risk of open positions of six foreign currencies } \\
\text { including US dollar, Euro, British Pound, Switzerland Frank, Norwegian Kroner and United } \\
\text { Emirate Dirham increase during the time horizon. The proposed study of this paper uses } \\
\text { historical daily prices of these currencies for a fiscal year of } 2011 \text { in one of private banks } \\
\text { located in Iran and measures the relative risk. The results of the implementation of two methods } \\
\text { of VaR and linear regression indicate that the risk of open positions increases during the time } \\
\text { horizon. }\end{array}$ \\
\hline
\end{tabular}
\end{abstract}

(C) 2012 Growing Science Ltd. All rights reserved.

\section{Introduction}

One of important issues in global economy is to reduce the risk associated with currencies held by central banks of countries. This would help reduce some of possible uncertainties in asset allocation and maintain reliable assets. Value at risk $(\mathrm{VaR})$ is one of the most important methods for measuring risk in currencies and there are literally many applications of this method on various currencies. De Santis and Gérard (1998) estimated and tested the conditional version of an international capital asset pricing model (ICAPM) using a parsimonious multivariate GARCH process. They provided a model, which includes both market and foreign exchange risk and both sources of risk are only determined when their prices were permitted to change over time. They reported that with the exception of the

\footnotetext{
* Corresponding author. Tel: $+98912-3443139$

E-mail addresses: m_khodaei@iau-tnb.ac.ir (M. KhodaeiValahzaghard) 
U.S. equity market, the premium for bearing currency risk often represents a substantial fraction of the total premium.

Phylaktis and Ravazzolo (2004) proposed a new an ICAPM, which incorporates foreign currency risk, and investigated the effect of capital market liberalization on the pricing of risks. Their model used some data from Pacific Basin financial markets and reported substantial evidence that not only currency risk was priced in both pre- and post-liberalization periods, but the model was superior to one which did not include currency risk. They recommended that an ICAPM neglecting currency risk cannot be specified, properly. Furthermore, the results explained that since the risk of currency was priced and investors were compensated they should not be discouraged by more flexible exchange rate regimes from investing in emerging markets.

Tan and Chan (2003) investigated whether the basic assumption of normality was sufficient for stress testing under the StressVaR framework. They built the StressVaR-x method to account for a fat-tailed distribution and the results indicated that the StressVaR-x only outperformed the StressVaR marginally at the $99 \%$ confidence level when they used the models to stress test a portfolio comprising of eight Asian currencies under severe stress in the recent years. They concluded that, at the $95 \%$ level, the StressVaR method provided better than the StressVaR-x method. Despite evidence of fat-tailed return distribution, they specified that the normality assumption could still be sufficient in stress testing.

Liu and Cao (2011) studied the effect towards foreign exchange market of 13 types of macroeconomic data using GARCH method, and found the released information of Sino-American monetary and retail trade had the biggest impact on foreign exchange market. They tried to implement the GARCH model with macro information based on the VaR technique to measure foreign exchange risk renewedly and realized that adding macro information into the model could increase the information of estimation, which could improve the VaR measurement results.

Huang and Guo (2006) studied the feasibility of creating a currency union in East Asia following closer monetary cooperation in recent years, empirically. They used VaR technique to find out different types of shocks in nine East Asian economies, with nine European Monetary Union countries adopted as benchmarks. They concluded that it could be beneficial for Hong Kong, Indonesia, Korea, Malaysia, Singapore and Thailand to take the lead in endorsing and fostering a common currency zone.

Bakshi et al. (2008) developed some techniques of stochastic discount factors in international economies, which generate stochastic risk premiums and stochastic skewness in currency options by approximating the models using time-series returns and option prices on three currency pairs. The results indicated that the average risk premium in Japan was larger than that in the US or the UK, the global risk premium was more persistent and volatile than the country-specific risk premiums, and investors responded differently to various shocks. They also determined high-frequency jumps in each economy but reported that only downside jumps were priced. Finally, their analysis specified that the risk premiums were economically compatible with movements in stock and bond market fundamentals.

Saleem and Vaihekoski (2010) investigated ICAPM and the pricing of global and local market risks as well as currency risk in the Russian stock market in terms of international investors' perspective using weekly data from 1999 to 2009. In this study, they utilized the multivariate GARCH-M and reported that currency risk to be priced in the Russian market. The price of currency risk was determined to be time-varying and influenced for instance by the price of oil. They also specified that the Russian market was partially segmented and the local market risk was priced in the market. 


\section{Research Methodology}

Data of research includes the necessary data for fiscal year of 2011 associated with a private bank collected on daily basis. Research data was selected by using non-probability targeted sampling method and volume sample was determined based on judgment of researcher. The information was collected from financial statistical system of private banks and according to goals of research and applying suitable formula, it was turned into variables of research. In order to measure and estimate risk of open position, VAR method has been adopted and they are analyzed using SPSS software. Risk model is general scheme for analyzing real-world problems, which is based on statistical and probability theories. A risk model consists of predicting distribution of probability for different events and studying level of their loss. Risk models process different data and create measurement criteria. In order to evaluate risks including: open position risk or market risk, it is possible to use from available standard models in the field of banking industry. Models for measuring risk are selected according to qualitative or quantitative degrees of statistical data. The proposed study uses VAR method to measure the risk of open position of private banks. A general mathematical model of VAR can be described as follows,

$\operatorname{Pr}\left\{\mathrm{p}_{0-} \mathrm{p}_{1 \geq \operatorname{VaR}}\right\} \leq \alpha$,

where $\mathrm{P}_{0}$ is portfolio value at time zero, $\mathrm{P}_{1}$ is portfolio value at time 1 and $\alpha$ is level of statistical error. This formula shows that probability of decreasing portfolio value in future period is higher than VAR and its maximum level is $\alpha$ i.e. probability of portfolio loss in future period is less than VAR as 1- $\alpha$. If cumulative distribution function of portfolio value in future period is shown as $F(p)$, its inverse mode i.e. $\mathrm{F}_{\mathrm{P}}^{-1}(\alpha)$ shows centile of portfolio value during progressive period. Therefore, VAR is calculated according to following formula,

$\mathrm{VaR}=\mathrm{P}_{0}-\mathrm{F}_{\mathrm{P}}^{-1}(\alpha)$,

where $\mathrm{F}_{\mathrm{P}}^{-1}(\alpha)$ is centile alpha for distributing value of portfolio.

VAR refers to maximum expected loss of assets or investment during specified period (one day, one week, one month) under ordinary market condition and certainty level i.e. this criterion is interpreted as follows: Based on this formula we make sure that during $\mathrm{N}$ future days surely investor does not lose more than V (Onak et al., 1998; Pearson, 2002).

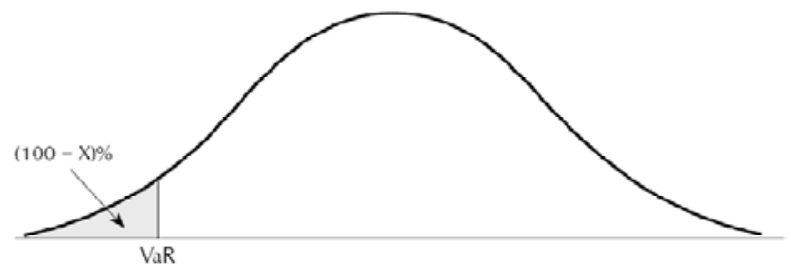

Fig. 1. Status of distribution VAR

In VAR method, there are two parameters of $\mathrm{N}$ and $\mathrm{X}$ representing time period and certainty level, respectively.

$$
\operatorname{VaR} \times \sqrt{N} 1 \text { day }=\mathrm{VaR} \text { during } \mathrm{N} \text { days }
$$

Under some cases where change at investment during successive days has equal independent normal distribution with zero average, the aforesaid formula is exactly correct and under other conditions, aforesaid formula is nearly correct. VAR summarizes different types of risks and senior management from many calculations of risk. Nowadays this method is greatly applied in companies and managers of banks and financial institutes. Through VAR, it is possible to target risk and determine budget for 
risk. Supervision organizations including: central bank, by using VAR determines their required capital for banks based on real nature of transaction tools and level of risk taking. Generally, 2 methods are defined for measuring VAR including: historical simulation and parametric model method; in which, the present research applies from historical simulation method.

\section{Analyzing data and hypothesis test}

\subsection{Analyzing data and calculating risk of open position (VAR)}

Value of VAR is calculated by using historical simulation method. The present research by observing information related to 204 working days during the fiscal year of 2011 has estimated risk of open position for future days of year 2011. Therefore, based on 204 daily effects, it is possible to obtain 292 scenarios for open position. Each of these scenarios offers a change level in open position of bank. According to normal distribution, the risk of open position of this period is calculated through following formula:

$\mu-1.64 \frac{\delta}{\sqrt{n}}$

where $\mu$ is average open position obtained from 293 possible scenarios and $\sigma$ is standard deviation. As it is indicated, in order to calculate VAR of Open Position, it is used from certainty level of $95 \%$ and cumulative normal distribution is unilateral $95 \%$ i.e. 1.64 .

\subsection{Hypothesis Test}

It seems that upon passing time the risk of Open Position of Private banks is increased; therefore, research hypothesis are as follows:

H1: The risk of Dollar Open Position in Private Banks is increased during the time horizon.

H2: The risk of Euro Open Position in Private Banks is increased during the time horizon.

H3: The risk of Pound Open Position in Private Banks is increased during the time horizon.

H4: The risk of Frank Open Position in Private Banks is increased during the time horizon.

H5: The risk of Dirham Open Position in Private Banks is increased during the time horizon.

H6: The risk of croon Open Position in Private Banks is increased during the time horizon.

In order to test these hypotheses, 2 semi-value of risk of Open Position of Private banks have been compared. Table 1 shows details of our testing for all six hypotheses.

Table 1

Results of comparing risk of Open Position between first and second half of year

\begin{tabular}{|c|c|c|c|c|c|c|c|c|}
\hline & \multirow{2}{*}{\multicolumn{4}{|c|}{ t-test for equality of Means }} & \multirow{2}{*}{\multicolumn{2}{|c|}{$\begin{array}{c}\text { Levene`s Test for } \\
\text { Equality of } \\
\text { Variances } \\
\end{array}$}} & \multicolumn{2}{|c|}{ Mean } \\
\hline & & & & & & & \multicolumn{2}{|c|}{ Group statistics } \\
\hline & $\begin{array}{c}\text { Mean } \\
\text { difference }\end{array}$ & sig & $\mathrm{df}$ & $\mathrm{T}$ & sig & $\mathrm{F}$ & $\begin{array}{l}\text { Second half } \\
\text { of year }\end{array}$ & $\begin{array}{c}\text { First half of } \\
\text { year }\end{array}$ \\
\hline Dollar & -4139496 & 0.000 & 202 & -7.910 & 0.000 & 49.850 & -4936862 & -9076359 \\
\hline Euro & -666111 & 0.000 & 202 & -7.910 & 0.000 & 49.850 & -230005 & -896116 \\
\hline Pound & -740.5 & 0.000 & 202 & -7.910 & 0.000 & 49.850 & -551.92 & -1292.43 \\
\hline Frank & -116826 & 0.000 & 202 & -7.910 & 0.000 & 49.850 & -91922.6 & -208748 \\
\hline Kroner & -829159.67 & 0.000 & 202 & -7.910 & 0.000 & 49.850 & -459890 & -1289049 \\
\hline Dirham & -2447794 & 0.000 & 202 & -7.910 & 0.000 & 49.850 & -639623 & -3087417 \\
\hline
\end{tabular}


As we can observe from the t-student values of 2 independent samples, the average risk at the second half is significantly higher than the average risk during the first half of year 2011. According to our results, the significance probability of test for comparing independent groups may be interpreted that the risk for US dollar, Euro, British Pound, Frank, Kroner and Emirate Dirham increases during the time horizon. Therefore, all research hypotheses, the risk of open position in private banks is increased during the studied time horizon, are confirmed.

\subsection{Regression Model}

In this section, we present a regression analysis to study the relationships between two variables of time and risk of open position.

Table 2

Results of regression analysis between variable of VAR for time and Open Position

\begin{tabular}{|c|c|c|c|c|c|c|c|c|}
\hline \multicolumn{2}{|c|}{ Open Position } & \multicolumn{2}{|c|}{$\begin{array}{c}\text { Unstandardized } \\
\text { coefficients }\end{array}$} & \multirow{2}{*}{$\begin{array}{c}\begin{array}{c}\text { Standardized } \\
\text { coefficients }\end{array} \\
\text { Beta }\end{array}$} & \multirow[t]{2}{*}{$\mathrm{t}$} & \multirow{2}{*}{$\begin{array}{l}\text { Sig } \\
(\mathrm{t})\end{array}$} & \multirow{2}{*}{$\begin{array}{l}\text { Sig } \\
(\mathrm{F})\end{array}$} & \multirow[t]{2}{*}{ R.square } \\
\hline & & $\mathrm{B}$ & Std.Error & & & & & \\
\hline \multirow{2}{*}{ Dollar } & Constant & -10000000 & 454460.7 & & -26.040 & 0.00 & \multirow{2}{*}{0.00} & \multirow{2}{*}{0.428} \\
\hline & Time & 47296.51 & 3844.443 & 0.654 & 12.303 & 0.00 & & \\
\hline \multirow{2}{*}{ Euro } & Constant & -9878954 & 73130.02 & & -18.322 & 0.00 & \multirow{2}{*}{0.00} & \multirow{2}{*}{0.427} \\
\hline & Time & 7610.768 & 618.663 & 0.654 & 12.303 & 0.00 & & \\
\hline \multirow{2}{*}{ Pound } & Constant & -1785.78 & 81.297 & & -21.996 & 0.00 & \multirow{2}{*}{0.00} & \multirow{2}{*}{0.428} \\
\hline & Time & 8.461 & 0.688 & 0.654 & 12.646 & 0.000 & & \\
\hline \multirow{2}{*}{ Frank } & Constant & -286582 & 12825.92 & & -22.344 & 0.000 & \multirow{2}{*}{0.00} & \multirow{2}{*}{0.430} \\
\hline & Time & 1334.815 & 108.499 & 0.654 & 12.857 & 0.000 & & \\
\hline \multirow{2}{*}{ Dirham } & Constant & -5000000 & 268734.70 & & -17.557 & 0.000 & \multirow[b]{2}{*}{0.00} & \multirow{2}{*}{0.422} \\
\hline & Time & 27967.68 & 2273.321 & 0.654 & 12.303 & 0.000 & & \\
\hline \multirow{2}{*}{ Kroner } & Constant & -2000000 & 91030.50 & & -20.229 & 0.000 & \multirow[b]{2}{*}{0.00} & \multirow{2}{*}{0.428} \\
\hline & Time & 9473.702 & 770.059 & 0.654 & 12.303 & 0.000 & & \\
\hline
\end{tabular}

According to the results of Table 2, we realize that we have reached the same results as previous one reported earlier using VAR method. According to level of $\mathrm{R}^{2}$ it is possible to say that more than 203 of changes at dependant variable (risk of Open Position) are described by time variable within final model.

\subsection{Regression model of Open Position is as follows}

Risk of US Dollar Open Position (VAR) $=-10000000+47296.51$ (Time)

Risk of Euro Open Position $($ VAR $)=-1000000+7610.768$ (Time)

Risk of British Pound Open Position $($ VAR $)=-1785.78+8.461$ (Time)

Risk of Switzerland Frank Open Position $(\mathrm{VAR})=-286582+1334.815$ (Time)

Risk of United Emirate Dirham Open Position (VAR) $=-5000000+27967.68$ (Time)

Risk of Kroner Open Position $($ VAR $)=-2000000+9473.702($ Time $)$

Again, all statistical values associated with these six regression analysis were held valid and they were meaningful. As we can observe, with an increase in time, the risks associated with all open position increase too. Therefore, there is a positive relationship between time and risk parameters. 


\section{Conclusion}

One of the most important issues in managing asset values is to reduce any negative effects of foreign currencies on balance sheet. In this paper, we have presented an empirical study to measure the relative existing risk associated with foreign currencies hold as part of assets in one of privately hold banks in Iran. The proposed model of this paper has implemented two methods to see whether there is any risk associated with six foreign currencies in time horizon including US dollar, Euro, British Pound, Switzerland Frank, Norwegian Kroner and United Emirate Dirham. The results of both value at risk as well as regression analysis have indicated that the risk of having these six foreign assets increases over time horizon.

\section{Acknowledgment}

The authors would like to thank the people and officials who helped us gather the necessary data. We are also grateful to anonymous referees' insights on earlier version of this paper.

\section{Reference}

Bakshi, G., Carr, P., \& Wu, L. (2008). Stochastic risk premiums, stochastic skewness in currency options, and stochastic discount factors in international economies. Journal of Financial Economics, 87(1), 132-156.

De Santis, G., \& Gérard, B. (1998). How big is the premium for currency risk? Journal of Financial Economics, 49(3), 375-412

Liu, X., \& Cao, H. (2011). Improvement of the VaR method for foreign exchange risk measurement based on macro information released. Systems Engineering Procedia, 1, 440-449.

Huang, Y., \& Guo, F. (2006). Is currency union a feasible option in East Asia?: A multivariate structural VAR approach. Research in International Business and Finance, 20(1), 77-94.

Onak, J., Jorion, M., Taleb, P., Derman, N., Putnam, E., Sandor, B., Jonas, R., et al. (1998). Roundtable: The Limits of VaR. Derivatives Strategy.

Phylaktis, K., \& Ravazzolo, F. (2004).Currency risk in emerging equity markets. Emerging Markets Review, 5(3), 317-339.

Pearson, N. (2002). Risk Budgeting: Portfolio Problem Solving with Value-at-Risk. John Wiley \& Sons.

Saleem, K., \& Vaihekoski, M. (2010). Time-varying global and local sources of market and currency risks in Russian stock market. International Review of Economics \& Finance, 19(4), 686-697

Tan, K.H., \& Chan, I.L. (2003). Stress testing using VaR approach-a case for Asian currencies. Journal of International Financial Markets, Institutions and Money, 13(1), 39-55. 